\title{
PENGARUH SERVICE RECOVERY TERHADAP LOYALITAS KONSUMEN MELALUI KEPUASAN KONSUMEN SEBAGAI VARIABEL INTERVENING (Studi pada Nasabah Bank BRI Cabang Malang)
}

\author{
Shofi 'Aliyatul Himmah \\ Mahasiswa Magister Manajemen Pascasarjana Universitas Islam Malang \\ Email: shofi.alyaa@gmail.com
}

\begin{abstract}
The purpose of this study was to determine the effect of service recovery on consumer loyalty with customer satisfaction as an intervening variable at the Malang branch of BRI Bank. This research uses quantitative methods. Sampling is done using incidental sampling techniques. The samples taken for this study were 100 customers of Malang Branch BRI Bank. Data retrieval is done using a questionnaire. The data analysis technique used is path analysis. This study concludes that service recovery has an effect on customer loyalty, service recovery has an effect on customer satisfaction, customer satisfaction influences customer loyalty and service recovery has an indirect effect on customer loyalty through customer satisfaction.
\end{abstract}

Keywords: Service Recovery, Customer Satisfaction, Consumer Loyalty, Bank BRI, Malang Branch BRI Bank

\section{PENDAHULUAN}

Bank menjadi bagian dari aktivitas bisnis masyarakat. Bank merupakan perusahaan yang memiliki kaitan erat dengan masyarakat dan dalam menawarkan produknya, bank berhadapan langsung dengan konsumen atau nasabahnya. Menurut data dari Badan Pusat Statistik menyatakan bahwa jumlah kantor bank persero mengalami kenaikan setiap tahunnya yaitu pada tahun 2015 sebanyak 17.809 kantor bank, pada tahun 2016 sebanyak 18.106 kantor bank, dan pada tahun 2017 sebanyak 18.262 kantor bank. Hal tersebut menunjukkan bahwa perusahaan perbankan mengalami perkembangan yang baik di masyarakat.

Bank sebagai perusahaan dituntut untuk memberikan pelayanan terbaiknya kepada konsumen. Namun tidak menutup kemungkinan akan adanya kesalahan atau kegagalan yang dilakukan oleh pihak perusahaan dalam melayani konsumennya, termasuk pihak bank kepada nasabahnya.

Kesalahan atau kegagalan dalam pelayanan kepada konsumen wajar terjadi dalam suatu perusahaan. Namun hal tersebut dapat mempengaruhi citra perusahaan bagi konsumen. Maka dari itu, perusahaan perlu melakukan service recovery atau pemulihan layanan yang bertujuan untuk mempertahankan konsumen dan meminimalisir rasa kecewa konsumen terhadap layanan perusahaan yang kurang maksimal. Menurut Kotler dan Keller (2013) mengenai kepuasan (satisfaction) adalah perasaan senang atau kecewa seseorang yang timbul karena membandingkan kinerja yang dipersepsikan produk (hasil) terhadap ekspektasi mereka. Jika produk atau layanan yang diperoleh oleh konsumen sesuai dengan ekspektasinya, maka konsumen akan melakukan pembelian berulang atau dapat disebut dengan konsumen yang loyal terhadap perusahaan. Oleh 
karena itu, loyalitas konsumen dan kepuasan konsumen memiliki kaitan yang erat.

Salah satu bank yang memiliki nasabah dengan jumlah terbesar di Indonesia adalah Bank Rakyat Indonesia. Pada praktiknya Bank Rakyat Indonesia tidak terlepas dari kegagalan layanan (service failure) dalam kegiatan operasionalnya. Adapun kegagalan layanan pada Bank BRI berupa ketidaksesuaian ekspektasi konsumen terhadap hasil dari pelayanan pegawai bank di kantor Unit BRI maupun pelayanan yang berhubungan dengan fasilitas bank seperti mesin ATM yang seringkali bermasalah. Kartu ATM tertelan oleh mesin ATM, mesin ATM kosong, jaringan bermasalah ketika sedang melakukan transaksi transfer, mobile banking error, dan sebagainya merupakan suatu kendala yang dialami oleh nasabah (konsumen). Namun apabila karyawan Bank Rakyat Indonesia dapat mengatasi hal tersebut dengan baik, maka konsumen akan tetap menunjukkan loyalitasnya pada perusahaan.

\section{KAJIAN TEORI \\ Service Recovery}

Perusahaan dikatakan baik apabila mampu memberikan pelayanan terbaiknya kepada konsumen, terutama perusahaan yang bergerak di bidang jasa. Menurut Gronroos dalam Tjiptono (2005) terdapat tiga kriteria pokok untuk kualitas pelayanan, yaitu outcome related, process-related, dan image related criteria. Ketiga unsur tersebut masih dapat dijabarkan lagi dalam enam dimensi, yaitu:

\section{Professionalism and skills}

Kemampuan, pengetahuan dan ketrampilan pada penyedia jasa, karyawan, system operasional, dan sumber daya fisik, dalam memecahkan masalah pelanggan secara professional.

2. Attitudes and Behavior

Konsumen merasa bahwa perusahaan menaruh perhatian dan berusaha untuk membantu dalam memecahkan masalah pelanggan secara spontan dan senang hati.

3. Accessibility and Flexibility

Menyediakan pelayanan oleh perusahaan yang dirancang dan dioperasionalkan agar konsumen mengakses dengan mudah serta bersifat fleksibel dalam menyesuaikan permintaan dan keinginan konsumen.

\section{Reliability and Trust worthiness}

Konsumen bisa mempercayakan segala sesuatunya kepada penyedia jasa beserta karyawan dan sistemnya.

\section{Recovery Proses}

Pengambilan tindakan oleh perusahaan untuk mengendalikan situasi dan mencari pendekatan yang tepat bila konsumen ada masalah.

\section{Reputation and Credibility}

Keyakinan konsumen bahwa operasi dari perusahaan dapat dipercaya dan memberikan nilai atau imbalan yang sesuai dengan pengorbanannya. Pelayanan yang diberikan perusahaan kepada konsumennya pada 
kenyataannya tidak sepenuhnya berjalan dengan baik. Tidak menutup kemungkinan terdapat kegagalan pelayanan. Adanya kegagalan dalam pelayanan membuat perusahaan harus menentukan sikap dengan baik untuk mempertahankan kepuasan dan loyalitas konsumennya.

Sudradjat, Kumara, dan Susandi (2014), mendefinisikan service recovery sebagai suatu tindakan yang diambil oleh suatu perusahaan untuk mempertahankan loyalitas konsumen dengan menunjukkan respon dan tindakan yang tepat pada keluhan konsumen.

\section{Kepuasan Konsumen}

Menurut Lovelock dan Lauren (2007) Kepuasan konsumen adalah keadaan emosional / reaksi setelah menerima penyerahan jasa, dapat berupa kemarahan, ketidakpuasan, kejengkelan, netralitas, kegembiraan dan kesenangan.

Definisi kepuasan konsumen menurut Zeithaml, Bitner dan Gremler (2013:80) adalah penilaian konsumen atas produk ataupun jasa dalam hal menilai apakah produk atau jasa tersebut telah memenuhi kebutuhan dan ekspektasi pelanggan. Jadi kepuasan konsumen berkaitan dengan ekspektasi yang ditampakkan oleh konsumen terhadap produk perusahaan.

\section{Loyalitas Konsumen}

Menurut Griffin dalam Sangadji dan Shopiah (2013:104), menyatakan bahwa: "loyalty is defined as non random purchase expressed over timed by some decision making unit". Berdasarkan definisi tersebut dapat dijelaskan bahwa loyalitas lebih mengacu pada wujud perilaku dari unit-unit pengambilan keputusan untuk melakukan pembelian secara terusmenerus terhadap barang atau jasa dari suatu perusahaan yang dipilih.

Loyalitas konsumen sendiri menurut Sheth dan Mittal dalam Tjiptono (2014:393) adalah "komitmen konsumen terhadap suatu merek, toko, atau pemasok berdasarkan sikap yang sangat positif dan tercermin dalam pembelian ulang yang konsisten".

\section{Kerangka Konseptual}

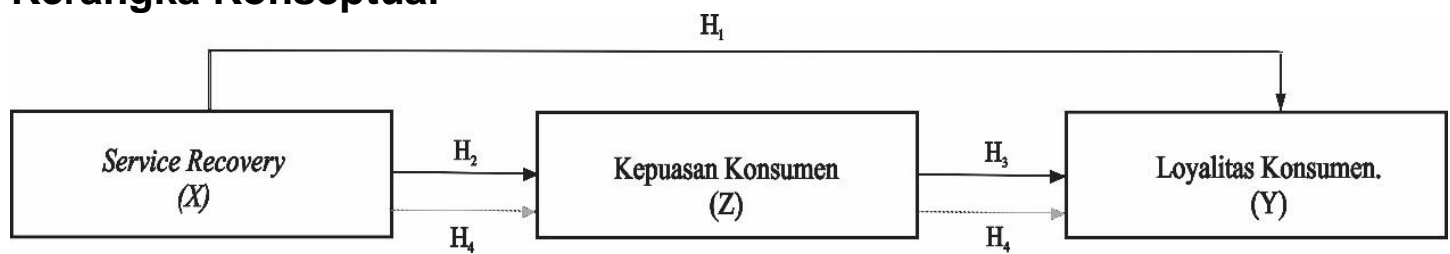

\section{Hipotesis Penelitian}

Berdasarkan kajian pustaka yang telah diuraikan sebelumnya, maka hipotesis dalam penelitian dapat dirumuskan sebagai berikut:

$\mathrm{H}_{1}$ : Service recovery berpengaruh langsung terhadap loyalitas konsumen.

$\mathrm{H}_{2}$ : Service recovery berpengaruh langsung terhadap kepuasan konsumen 
$\mathrm{H}_{3}$ : Kepuasan konsumen berpengaruh langsung terhadap loyalitas konsumen.

$\mathrm{H}_{4} \quad$ : Service recovery berpengaruh tidak langsung terhadap loyalitas konsumen melalui kepuasan konsumen.

\section{METODE PENELITIAN}

Jenis penelitian yang digunakan oleh peneliti yaitu penelitian kuantitatif. Metode penelitian kuantitatif dapat diartikan sebagai metode penelitian yang berlandaskan pada filsafat positivisme, digunakan untuk meneliti pada populasi atau sampel tertentu, teknik pengambilan sampel pada umumnya dilakukan secara random, pengumpulan data menggunakan instrumen penelitan, analisis data bersifat statistik dengan tujuan untuk menguji hipotesis yang telah ditetapkan. (Sugiyono, 2013 : 13).

\section{Lokasi Penelitian}

Lokasi penelitian pada penelitian ini dilakukan di PT. Bank BRI Cabang Malang yang berlokasi di Jalan Letjend Sutoyo No. 105 Lowokwaru Malang.

\section{Waktu Penelitian}

Waktu penelitian kurang lebih berlangsung selama 6 bulan, mulai bulan Februari sampai dengan bulan Juli 2019.

\section{Populasi}

Populasi dalam penelitian ini adalah seluruh konsumen Bank BRI Cabang Malang Jalan Letjen Sutoyo No 105 Lowokwaru Malang. Penelitian ditujukan kepada konsumen yang pernah mengalami masalah dengan pelayanan maupun fasilitas pada Bank BRI Cabang Malang.

\section{Sampel}

Pengambilan sampel dilakukan dengan menggunakan teknik incidental sampling. Sampel yang diambil dalam penelitian ini yaitu konsumen Bank BRI Cabang Malang. Jumlah sampel yang diambil dalam penelitian ini menggunakan rumus Wibisono karena jumlah populasi tidak diketahui.

$$
\begin{aligned}
& \mathrm{N}=\left\{\frac{((\mathrm{Za} / 2) \cdot \sigma)}{\mathrm{e}}\right\}^{2} \\
& \mathrm{~N}=\left\{\frac{(1,96 \cdot 0,25)}{5 \%}\right\}^{2} \\
& \mathrm{~N}=96,4 \text { dibulatkan menjadi } 96
\end{aligned}
$$

Rumus Sampel Wibisono Tahun 2005

Dimana:

$\mathrm{N} \quad=$ jumlah sampel

$\mathrm{Za} / 2=$ nilai dari tabel distribusi normal atas tingkat keyakinan $95 \%$ $=1,96$. 
$\sigma=$ standar deviasi $25 \%$

e $\quad=$ error (batas kesalahan $=5 \%$ )

Batas kesalahan atau margin of error dalam penelitian ini adalah 5\%, sehingga tingkat akurasinya sebesar 95\%. Sampel yang diambil untuk mengisi kuesioner sejumlah 96 responden.

Penelitian ini menggunakan tiga variabel yaitu Service Recovery sebagai variabel eksogen $(X)$, Loyalitas konsumen sebagai variabel endogen $(Y)$ dan Kepuasan Konsumen sebagai variabel intervening $(Z)$.

\section{HASIL ANALISIS DATA Hasil Uji Instrumen Penelitian}

Berdasarkan hasil perhitungan yang dilakukan diketahui bahwa semua item pernyataan pada masing-masing variabel memiliki $r_{\text {hitung }}>r_{\text {tabel }}$ $(0,361)$ atau nilai signifikansinya lebih kecil dari taraf nyata $5 \%$ sehingga disimpulkan item-item pernyataan tersebut telah valid.

Berikut merupakan hasil uji reliabilitas pada masing-masing variabel.

Tabel

Hasil Uji Reliabilitas

\begin{tabular}{|c|c|c|}
\hline Variabel & Alpha Cronbach & Keterangan \\
\hline Service Recovery $(\mathrm{X})$ & 0,730 & Reliabel \\
\hline $\begin{array}{c}\text { Kepuasan Konsumen } \\
(\mathrm{Z})\end{array}$ & 0,625 & Reliabel \\
\hline Loyalitas Konsumen $(\mathrm{Y})$ & 0,659 & Reliabel \\
\hline
\end{tabular}

Berdasarkan tabel di atas diketahui bahwa nilai Alpha Crobach pada variabel independen dan dependen berada di atas 0,6 sehingga dapat disimpulkan bahwa variabel tersebut telah reliabel.

\section{Distribusi Hasil Penelitian}

Secara keseluruhan, rata-rata jawaban responden pada variabel service recovery sebesar 4,26.

Secara keseluruhan rata-rata jawaban responden pada variabel kepuasan konsumen sebesar 4,21.

Secara keseluruhan rata-rata jawaban responden pada variabel loyalitas konsumen sebesar 4,10.

\section{Uji Asumsi Normalitas Residual Regresi}

Tabel

Hasil Uji Asumsi Normalitas

\begin{tabular}{|c|c|c|c|}
\hline Persamaan Struktural & $\begin{array}{c}\text { Kolmogorov-Smirnov } \\
\mathrm{Z}\end{array}$ & Nilai sig. & Keterangan \\
\hline $\mathrm{X} \rightarrow \mathrm{Z}$ & 0,948 & 0,330 & Berdistribusi Normal \\
\hline $\mathrm{X}$ dan $\mathrm{Z} \rightarrow \mathrm{Y}$ & 0,865 & 0,443 & Berdistribusi Normal \\
\hline
\end{tabular}

Keterangan: $\mathrm{X}=$ Service Recovery, $\mathrm{Z}=$ Kepuasan Konsumen, $\mathrm{Y}=$

Loyalitas Konsumen 
Berdasarkan hasil pengujian normalitas pada tabel di atas diketahui bahwa nilai signifikansi residual regresi yang terbentuk lebih besar dari taraf nyata $5 \%$ sehingga dapat dikatakan bahwa asumsi normalitas tersebut terpenuhi.

\section{Uji Asumsi Heterokedastisitas}

Tabel

Hasil Uji Glejser

\begin{tabular}{|c|c|c|}
\hline Variabel Bebas & Sig. & Keterangan \\
\hline $\begin{array}{c}\text { Persamaan Struktural 1 } \\
\text { X }\end{array}$ & 0,961 & Tidak terjadi Heteroskedastisitas \\
\hline $\begin{array}{c}\text { Persamaan Struktural 2 } \\
\text { X }\end{array}$ & 0,949 & Tidak terjadi Heteroskedastisitas \\
Z & 0,909 & Tidak terjadi Heteroskedastisitas \\
\hline
\end{tabular}

Keterangan: $\mathrm{X}=$ Service Recovery, $\mathrm{Z}=$ Kepuasan Konsumen, $\mathrm{Y}=$ Loyalitas Konsumen

Berdasarkan tabel diatas diketahui bahwa pada masing-masing variabel diperoleh nilai sig. $>0,05$ maka disimpulkan tidak terjadi heteroskedastisitas.

\section{Uji Asumsi Linieritas}

Tabel

Hasil Uji Linieritas

\begin{tabular}{|c|c|c|c|}
\hline Variabel independen & Variabel dependen & Sig. & Keterangan \\
\hline Service Recovery $(\mathrm{X})$ & Kepuasan Konsumen $(\mathrm{Z})$ & 0,000 & Berhubungan Linier \\
\hline Service Recovery $(\mathrm{X})$ & \multirow{2}{*}{ Loyalitas Konsumen $(\mathrm{Y})$} & 0,000 & Berhubungan Linier \\
Kepuasan Konsumen $(\mathrm{Z})$ & 0,000 & Berhubungan Linier \\
\hline
\end{tabular}

Hasil uji linieritas menunjukkan signifikansi masing-masing hubungan lebih kecil dari alpha $5 \%(0,050)$ sehingga disimpulkan bahwa antar variabel tersebut terdapat hubungan yang linier atau dengan kata lain asumsi linieritas terpenuhi.

\section{Analisis Jalur}

Pengaruh Antar Variabel dan Persamaan Jalur

Tabel

Pengaruh Antar Variabel

\begin{tabular}{|c|c|c|c|c|}
\hline Pengaruh & Koefisien Jalur & t-hitung & signifikansi & $\mathrm{R}^{2}$ \\
\hline $\mathrm{X} \rightarrow \mathrm{Z}$ & 0,583 & 6,958 & 0,000 & $34,0 \%$ \\
\hline Total & & & & $34,0 \%$ \\
\hline $\mathrm{X} \rightarrow \mathrm{Y}$ & 0,473 & 4,796 & 0,000 & $27,2 \%$ \\
\hline
\end{tabular}




\begin{tabular}{|c|c|c|c|c|}
\hline Pengaruh & Koefisien Jalur & t-hitung & signifikansi & $\mathrm{R}^{2}$ \\
\hline $\mathrm{Z} \rightarrow \mathrm{Y}$ & 0,229 & 2,326 & 0,022 & $13,1 \%$ \\
\hline Total & & & & $40,3 \%$ \\
\hline
\end{tabular}

Keterangan: $\mathrm{X}=$ Service Recovery, $\mathrm{Z}=$ Kepuasan Konsumen, $\mathrm{Y}=$ Loyalitas Konsumen

\section{Koefisien Determinasi Total}

Koefisien determinasi total menjelaskan mengenai seberapa besar model jalur (path) yang terbentuk dalam menjelaskan data yang digunakan dalam penelitian. Besar nilai koefisien determinasi berkisar antara $0 \%$ hingga $100 \%$, di mana semakin tinggi koefisien determinasi maka semakin baik pula model dalam menjelaskan data yang digunakan.

$$
\mathrm{R}_{\mathrm{m}}^{2}=1-[(1-0,340) \times(1-0,403)]=0,606
$$

Koefisien determinasi total yang didapatkan berdasarkan hasil perhitungan model path adalah sebesar 0,606 yang menunjukkan bahwa model path yang digunakan dapat menjelaskan sebesar $60,6 \%$ data yang digunakan dalam penelitian.

\section{Pengujian Hipotesis}

Tabel

Pengaruh Langsung

\begin{tabular}{|c|c|c|c|c|}
\hline Pengaruh & Koefisien Jalur & Standar Error & t-hitung & signifikansi \\
\hline$X \rightarrow Z$ & 0,583 & 0,059 & 6,958 & 0,000 \\
$X \rightarrow Y$ & 0,473 & 0,071 & 4,796 & 0,000 \\
$Z \rightarrow Y$ & 0,229 & 0,100 & 2,326 & 0,022 \\
\hline
\end{tabular}

Keterangan: $\mathrm{X}=$ Service Recovery, $\mathrm{Z}=$ Kepuasan Konsumen, $\mathrm{Y}=$ Loyalitas Konsumen

Hasil pengujian pengaruh langsung service recovery terhadap kepuasan konsumen diperoleh t-hitung $(6,958)$ yang lebih besar dari ttabel $(1,985)$ atau signifikansi $(0,000)$ lebih kecil dari alpha 5\% $(0,050)$ maka disimpulkan terdapat pengaruh positif dan signifikan service recovery terhadap kepuasan konsumen.

Hasil pengujian langsung service recovery terhadap loyalitas konsumen diperoleh t-hitung $(4,796)$ yang lebih besar dari t-tabel $(1,985)$ atau signifikansi $(0,000)$ lebih kecil dari alpha $5 \%(0,050)$ maka disimpulkan terdapat pengaruh positif dan signifikan service recovery terhadap loyalitas konsumen.

Hasil pengujian langsung kepuasan konsumen terhadap loyalitas konsumen diperoleh t-hitung $(2,326)$ yang lebih besar dari t-tabel $(1,985)$ atau signifikansi $(0,022)$ lebih kecil dari alpha $5 \%(0,050)$ maka 
disimpulkan terdapat pengaruh positif dan signifikan kepuasan konsumen terhadap loyalitas konsumen.

Tabel

Pengaruh Tidak Langsung

\begin{tabular}{|c|c|c|c|c|}
\hline Pengaruh & Koefisien Jalur & Standar Error & t-hitung & Sig. \\
\hline $\mathrm{X} \rightarrow \mathrm{Z}$ & 0,583 & 0,059 & 6,958 & 0,000 \\
$\mathrm{Z} \rightarrow \mathrm{Y}$ & 0,229 & 0,100 & 2,326 & 0,022 \\
& $0,583 \times 0,229$ & $\sqrt{ }\left(0,583^{2} \times 0,100^{2}+0,229^{2} \times\right.$ & $0,134 / 0,060$ & 0,028 \\
$\mathrm{X} \rightarrow \mathrm{Z} \rightarrow \mathrm{Y}$ & $=0,134$ & $\left.0,059^{2}\right)$ & $=2,231$ & \\
& $=0,060$ & \\
\hline
\end{tabular}

Keterangan: $\mathrm{X}=$ Service Recovery, $\mathrm{Z}=$ Kepuasan Konsumen, $\mathrm{Y}=$ Loyalitas Konsumen

Berikut ini disajikan diagram path berdasarkan hasil analisis yang telah dilakukan:

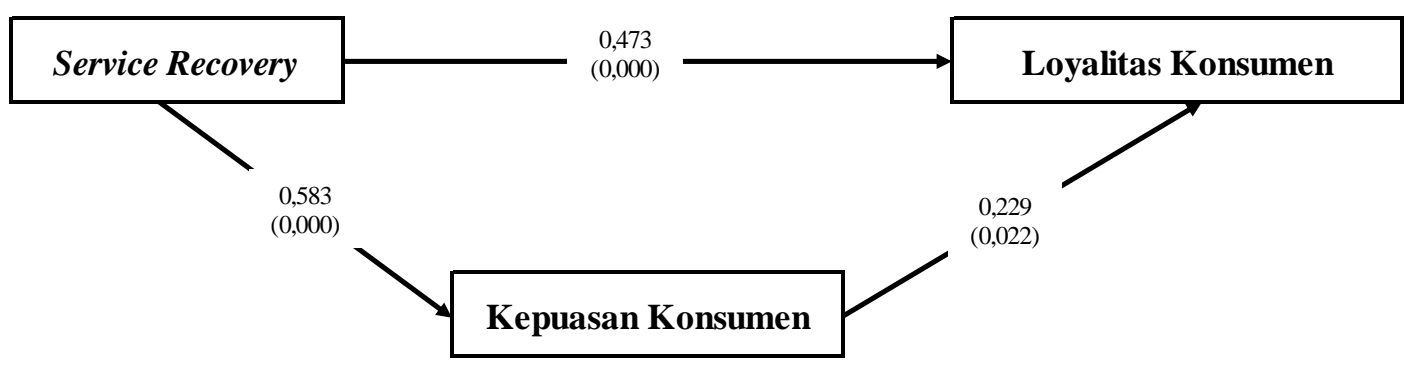

Gambar Diagram Jalur Path

\section{PEMBAHASAN}

\section{Pengaruh Service Recovery terhadap Kepuasan Konsumen}

Hasil pengujian data yang dilakukan, dapat disimpulkan bahwa terdapat pengaruh positif dan signifikan service recovery terhadap kepuasan konsumen. Hasil penelitian ini didukung oleh penelitian serupa yang dilakukan oleh Ghanbari, Esfandiari, Maghazei dan Khorasani (2012) yang menyatakan bahwa terdapat pengaruh langsung dan signifikan variabel service recovery terhadap variabel kepuasan konsumen.

Berdasarkan distribusi jawaban responden pada variabel service recovery, rata-rata jawaban yang diberikan adalah setuju pada semua item pernyataan yang diajukan. Rata-rata jawaban tertinggi terdapat pada item pernyataan mengenai penyediaan sarana untuk menyampaikan keluhan bagi konsumen. Responden setuju bahwa Bank BRI Cabang Malang menyediakan ruang untuk menyampaikan keluhan bagi konsumen. Hal ini berarti bahwa pihak bank memiliki sarana dalam menghimpun keluhan konsumen untuk kemudian disikapi dan diselesaikan oleh pihak bank. Hanya saja berdasarkan jawaban responden, profesionalisme perusahaan dalam menangani keluhan konsumen berada pada rata-rata terendah, hal ini dapat diartikan bahwa Bank BRI masih harus meningkatkan kualitas 
pelayanannya untuk menunjang profesionalisme dalam menangani keluhan yang diajukan oleh konsumen.

Sudradjat, Kumara, dan Susandi (2014), mendefinisikan service recovery sebagai suatu tindakan yang diambil oleh suatu perusahaan untuk mempertahankan loyalitas konsumen dengan menunjukkan respon dan tindakan yang tepat pada keluhan konsumen.

Tindakan tepat yang dilakukan oleh pihak bank ketika menangani keluhan yang disampaikan oleh konsumen akan berdampak baik bagi kedua belah pihak. Bagi pihak konsumen, penanganan keluhan secara tepat akan mampu mengubah kekecewaan yang dialami oleh konsumen menjadi perasaan puas terhadap kinerja bank sehingga secara tidak langsung hal tersebut dapat meningkatkan reputasi bank. Reputasi yang baik tentunya akan mampu menarik minat masyarakat yang lebih luas untuk menjadi konsumen dari Bank BRI di masa mendatang.

\section{Pengaruh Service Recovery terhadap Loyalitas Konsumen}

Berdasarkan hasil analisis data diperoleh kesimpulan bahwa service recovery berpengaruh langsung pada loyalitas konsumen. Hasil penelitian ini didukung oleh penelitian serupa yang dilakukan oleh Agipta dan Wardhana (2018) yang menyatakan bahwa terdapat pengaruh langsung dan signifikan variabel service recovery terhadap variabel loyalitas konsumen.

Berdasarkan distribusi jawaban responden pada variabel loyalitas konsumen menunjukkan bahwa rata-rata responden menjawab setuju pada item pernyataan yang diajukan. Hasil menunjukkan bahwa konsumen Bank BRI tidak segan merekomendasikan produk bank kepada orang lain. Hal ini menunjukkan bahwa Bank BRI telah berhasil menumbuhkan loyalitas pada konsumennya. Sebagaimana menurut Hasan (2008) keadaan yang seperti dipaparkan di atas merupakan bentuk tahapan loyalitas tindakan yang berhubungan dengan sikap pasca-konsumsi konsumen terhadap produk Bank BRI dihubungkan dengan kepuasan terhadap produk yang dirasakan oleh konsumen, sehingga konsumen merekomendasikan produk kepada orang lain.

Rata-rata jawaban terendah terdapat pada item pernyataan terletak pada indikator kekebalan daya tarik produk sejenis. Berdasarkan hasil tersebut, dapat disimpulkan bahwa konsumen Bank BRI rentan menggunakan produk sejenis dari bank lain, semisal produk tabungan, produk e-money, dll. Hal ini dapat dijadikan sebagai bahan evaluasi bagi pihak Bank BRI untuk dapat meningkatkan kualitas dari produk yang ditawarkan. Bank BRI dapat pula mendiferensiasikan produknya ke berbagai macam jenis, berdasarkan pada kebutuhan konsumen, sehingga ketika membutuhkan jenis produk tertentu tidak harus mencari pada bank lain.

\section{Pengaruh Kepuasan Konsumen terhadap Loyalitas Konsumen}

Berdasarkan hasil analisis data diperoleh kesimpulan bahwa kepuasan konsumen berpengaruh langsung pada loyalitas konsumen. 
Hasil penelitian ini didukung oleh penelitian serupa yang dilakukan oleh Zakky (2018) menunjukkan bahwa kepuasan konsumen berpengaruh langsung terhadap loyalitas konsumen.

Berdasarkan distribusi jawaban responden pada variabel kepuasan konsumen menunjukkan bahwa rata-rata responden menjawab setuju pada item pernyataan yang diajukan. Rata-rata tertinggi jawaban responden yaitu pada indikator komunikasi. Konsumen memiliki kepuasan yang tinggi terhadap cara komunikasi karyawan bank BRI. Komunikasi yang baik dan jelas akan memudahkan konsumen dalam menerima informasi yang disampaikan oleh karyawan Bank BRI, sehingga terjadinya kesalahpahaman dalam berkomunikasi dapat diminimalisir.

Berdasarkan angket yang didistribusikan kepada konsumen menunjukkan bahwa tingkat kepuasan konsumen terhadap mesin ATM Bank BRI berada pada rata-rata terbawah dari jawaban item pernyataan yang diajukan. Hal ini menunjukkan bahwa konsumen merasa kualitas ATM Bank BRI perlu ditingkatkan agar kepuasan konsumen terhadap kinerja bank tetap terjaga. Mesin ATM merupakan sebuah fasilitas yang diberikan oleh Bank BRI yang dapat membantu kegiatan operasional keuangan konsumen sehari-hari. Oleh karena itu apabila mesin ATM dapat bekerja dengan baik, maka kegiatan sehari-hari konsumen dapat lebih efektif, begitu pula sebaliknya. Fasilitas yang baik tentunya akan berdampak pada kepuasan konsumen terhadap Bank BRI.

Tingkat kepuasan yang baik akan berdampak bagi loyalitas konsumen dan bank. Loyalitas berhubungan dengan kesetiaan konsumen terhadap Bank BRI. Penggunaan lebih dari satu produk yang disediakan oleh Bank BRI dapat disebut sebagai loyalitas konsumen. Hal ini sesuai dengan pernyataan Morais dalam Sangadji dan Shopiah (2013:104), bahwa loyalitas konsumen adalah komitmen konsumen terhadap suatu merek toko, atau pemasok berdasarkan sikap yang sangat positif dan tercermin dalam pembelian ulang yang konsisten.

Kepuasan konsumen dengan loyalitas konsumen saling berhubungan erat satu sama lain. Pihak Bank BRI harus memperhatikan tingkat kepuasan konsumen untuk mempertahankan loyalitasnya. Bank BRI dapat meningkatkan kualitas pelayanannya sebagai bentuk untuk menjaga kepuasan dan loyalitas konsumennya. Karena loyalitas konsumen yang tinggi terhadap Bank BRI akan mampu mempertahankan kelangsungan hidup Bank BRI di masa mendatang.

\section{Pengaruh Service Recovery terhadap Loyalitas Konsumen dengan Kepuasan Konsumen sebagai Variabel Intervening}

Hasil pengujian pengaruh tidak langsung service recovery terhadap loyalitas konsumen melalui kepuasan konsumen dapat disimpulkan bahwa terdapat pengaruh tidak langsung yang signifikan dengan arah positif antara service recovery terhadap loyalitas konsumen melalui kepuasan konsumen.

Konsumen yang mendapatkan service recovery dengan baik tentunya akan merasa puas dengan layanan yang diberikan oleh pihak bank. Kepuasan tersebut dapat menimbulkan penggunaan jasa Bank BRI 
secara berulang di kemudian hari. Sheth dan Mittal dalam Tjiptono (2014:393) menyatakan bahwa loyalitas konsumen merupakan komitmen konsumen terhadap suatu merek, toko, atau pemasok berdasarkan sikap yang sangat positif dan tercermin dalam pembelian ulang yang konsisten.

Bank BRI memiliki beberapa produk yang ditawarkan. Tidak hanya berupa simpanan, tetapi juga pinjaman hingga kartu e-money. Konsumen yang merasa puas dengan layanan Bank BRI tentunya tidak akan ragu menggunakan produk lain dari bank yang telah disediakan. Selain itu, konsumen tidak akan segan merekomendasikan keunggulan dari Bank BRI kepada orang lain.

Berdasarkan penelitian yang telah dilakukan dapat dikemukakan bahwa apabila Bank BRI memiliki service recovery yang baik diikuti dengan kepuasan konsumen yang baik, maka loyalitas konsumen akan semakin meningkat. Apabila Bank BRI memiliki service recovery yang tidak baik diikuti dengan kepuasan konsumen yang rendah, maka loyalitas konsumen akan menurun.

\section{SIMPULAN DAN SARAN}

Berdasarkan hasil pengujian data yang diperoleh pada masingmasing variabel didapatkan hasil sebagai berikut:

1. Service recovery berpengaruh positif dan signifikan terhadap loyalitas konsumen Bank BRI Cabang Malang.

2. Service recovery berpengaruh positif dan signifikan terhadap kepuasan konsumen Bank BRI Cabang Malang.

3. Kepuasan konsumen berpengaruh positif dan signifikan terhadap loyalitas konsumen Bank BRI Cabang Malang.

4. Terdapat pengaruh tidak langsung service recovery terhadap loyalitas konsumen melalui kepuasan konsumen Bank BRI Cabang Malang.

Berdasarkan hasil penelitian dapat disimpukan bahwa service recovery yang dilakukan oleh Bank BRI Cabang Malang berpengaruh terhadap loyalitas konsumen melalui kepuasan konsumen sebagai variabel intervening.

Pada proses pembuatan hasil penelitian ini, peneliti mengajukan beberapa saran yang dapat dipertimbangkan bagi Bank BRI Cabang Malang dan peneliti selanjutnya sebagai berikut:

1. Bagi Bank BRI Cabang Malang

Berdasarkan hasil penelitian yang dilakukan oleh peneliti, service recovery berpengaruh terhadap loyalitas dan kepuasan konsumen, oleh karena itu ketika perusahaan mendapatkan keluhan dari konsumen, karyawan harus mampu mengatasi masalah tersebut dengan baik agar tingkat kepuasan dan kepercayaan konsumen tetap terjaga dengan baik. Kepuasan dan loyalitas konsumen perlu dipertahankan agar perusahaan tidak kehilangan konsumen dan dalam jangka waktu depan dapat meningkatkan pendapatan perusahaan.

2. Bagi Peneliti selanjutnya

Penelitian yang dilakan oleh peneliti memiliki keterbatasan dalam jumlah variabel yang digunakan. Peneliti hanya menggunakan satu variabel eksogen yaitu service recovery, variabel intervening yaitu kepuasan 
konsumen dan variabel endogen yaitu loyalitas konsumen. Diharapkan pada penelitian selanjutnya dapat menambah jumlah variabel sehingga hasil yang diperoleh lebih maksimal.

\section{DAFTAR PUSTAKA}

Abbas Ghanbari, Hamed Esfandiari, Omid Maghazei dan Sasan Torabzadeh Khorasani. 2012. The Impact of Service Recovery on Customer. Archives Des Science. Vol 65, No. 11; Nov 2012.

Agipta, Hegy Priatama dan Wardhana, Aditya. 2018. Pengaruh Service Recovery terhadap Loyalitas Pangkalan Gas Elpiji $3 \mathrm{~kg}$ (Studi Kasus pada PT. Amas Niaga Pratama). Jurnal e-Proceeding of Management Vol 5 : No 2 Agustus 2018 page 2748.

Ali Hasan. 2008. Marketing. Jakarta : PT. Buku Kita.

Alma, Buchari. 2005. Manajemen Pemasaran dan Pemasaran Jasa. Bandung: CV. Alfabeta

Anjarsari, Ekky Ayu. 2015. Pengaruh Service Recovery terhadap Kepuasan Konsumendan Loyalitas Pelanggan. Jurnal.

Cristina, Ucik. 2016. Analisis Pengaruh Kualitas Pelayanan dan Loyalitas Pegawai Kementrian Agama Kota Malang terhadap Kepuasan Jamaah Haji. Tesis, Tidak Dipublikasikan. Universitas Islam Malang.

Fatricia, Raja dan Priadi, Eka. 2018. Pengaruh Service Recovery terhadap Kepuasan KonsumenSpeedy. Jurnal Digest Marketing vol 3 no.1, Januari-Juli, 2018.

Ghozali, Imam. 2006. Aplikasi Analisis Multivariate dengan Program IBM SPSS. Semarang: Badan Penerbit Unibersitas Diponegoro.

2009. Aplikasi Analisis Multivariant dengan Program IMB SPSS 19. Semarang : UNDIP.

2011. Aplikasi Analisis Multivariant dengan Program IMB SPSS 19. Semarang : UNDIP.

2013. Aplikasi Analisis Multivariate dengan Program IBM SPSS 21 Update PLS Regresi. Semarang: Badan Penerbit Universitas Diponegoro.

2016. Aplikasi Analisis Multivariate dengan Program IBM SPSS 23(Edisi). Cetakan ke VII Semarang: Badan Penerbit Universitas Diponegoro.

Griffin, Jill. 2005. Customer Loyality: Menumbuhkan dan Mempertahankan Kesetiaan Pelanggan. Jakarta: Erlangga.

Hasan, A. 2008. Marketing. Yogyakarta: Medja Pressindo

Hurriyati, Ratih. 2013. Bauran Pelayanan dan Loyalitas Konsumen. Bandung : Alfabeta

Istianto, Jhon Hendra \& Tyra Maria Josephine. 2011. Analisis pengaruh kualitas layanan terhadap kepuasan pelanggan. Jurnal Ekonomi dan Informasi Akuntansi.

Kau, Ah-Keng dan Elizabeth Wan-Yiun Loh. 2006. The Effects of Service Recovery on Consumer Satisfaction: A Comparison Between Complainants dan Non Complainants. Journal of Service Marketing. 20(2): 101-111. 
Kotler, Philip. 2007. Manajemen Pemasaran Edisi Milnium, Jilid 2. Jakarta: PT. Prenhallindo.

Kotler, Philip, \& Kevin Lane Keller. 2009. Manajemen Pemasaran Jilid 2. Edisi 13. Alih Bahasa. Jakarta: Erlangga

Lovelock, C., et al., .2010. Pemasaran Jasa. Jakarta: Erlangga

Nurdiansyah, Firman. 2015. Pengaruh Kualitas Layanan terhadap Kepuasan dan Dampaknya pada Loyalitas Pengunjung Grapari Telkomsel di Malang. Tesis, Tidak Dipublikasikan. Universitas Islam Malang.

Sangadji, Etta Mamang \& Sopiah. 2013. Perilaku Konsumen - Pendekatan Praktis disertai Himpunan Jurnal Penelitian. Yogyakarta: ANDI.

Sanusi, Anwar. 2011. Metodologi Penelitian Bisnis. Salemba Empat. Jakarta

Sudradjat, A.S., Kumara, G.K., \& Susandi, N. (2014). Complaint Handling and Service Recovery Analysis at Low Cost Carrier Airline and Effects on Customer Satisfaction in Indonesia. International Journal of Science and Research, 3(1), 181-186.

Sugiyono. 2013. Metode Penelitian Bisnis. Bandung: Alfabeta

Tjiptono, Fandy dan G. Chandra. 2005. Service, Quality, \& Satisfaction. Penerbit Andi. Yogyakarta.

Tjiptono, Fandy. 2011. Pemasaran Jasa. Yogyakarta : Penerbit ANDI. 2014. Pemasaran Jasa. Yogyakarta : Penerbit ANDI.

Umar, Husein. 2008. Metode Riset Bisnis. Jakarta: PT. Gramedia Pustaka Utama

Wibisono, Yusuf. 2005. Metode Statistik.Yogyakarta: Gadjah Mada University Press

Zakky, Lubis Fajris. 2018. Pengaruh Brand Image, Brand Trust, Word of Mouth dan Ease of Use terhadap Loyalitas Konsumen dengan Kepuasan Konsumen sebagai Variabel Intervening pada Pengguna Aplikasi M-Commerce (Studi pada Pengguna Aplikasi "Belanjasayur" di Kota Malang). Tesis, Tidak Dipublikasikan. Universitas Islam Malang.

Zeithamal, Valerie A., Mary Jo Bitner \& Dawayne D. Gemler. 2013. Service Marketing Integrating Customer Focus Across the Firm. 4thed. Mc. New York : Graw Hill.

Zemke, R., dan Bell, C., 1990. Service Recovery: Doing it Right the Second Time. Journal Training.

https://www.customerthermometer.com/customer-retention-ideas/the-

service-recovery-paradox/ diakses pada Senin, 26 November 2018 pukul 9.31am

http://investorsadar.com/analisa-bank-bri-bbri-konsisten-profit-danpertumbuhan-besar/ diakses pada Senin, 26 November 2018 pukul 11.19am

http://yud1.csui04.net/2013/02/28/service-recovery-paradox/ diakses pada Senin, 26 November 2018 pukul 11.30am 